\title{
PERUBAHAN UNDANG-UNDANG DASAR 1945: SEBUAH KENISCAYAAN
}

\author{
Lindra Darnela \\ Fakultas Syari'ah UIN Sunan Kalijaga Yogyakarta \\ Email:lindra@yahoo.co.id
}

\begin{abstract}
Abstrak
The 1945 Constitution of Indonesian Republic (UUD 1945) has been a set of sacred norm and national administration reference for four decades. However, since the reform era Indonesian people are now able to review, discuss, and criticize its content consistent with recent national progress. Amendment of the 1945 Constitution becomes a new momentum to improve the state's management, which has apparently deviated from the country's foremost objectives written in the national philosophy of "Pancasila". In response to the amendment, there are three diverse perspectives that highlight its process. First, there are people who wish to keep the originality of the 1945 Constitution. Second, there are individuals who agree with the last amendment of the 1945 Constitution. Lastly, there is a public view which supports the continuous amendment process of the 1945 Constitution until it achieves the supreme mandate of the country and the people. This paper will focus on the third perspective as the main issue of discussion.

UUD 1945 telah menjadi norma yang sakral dan referensi administrasi nasional selama empat dekade ini.Akan tetapi, sejak era reformasi masayarakat Indonesia mampu mereview, mendiskusikan dan mengkritik isi dari UUD 1945 seiring dengan keajuan bangsa saat ini. Perubahan UUD 1945 menjadi momentum untuk meningkatkan manajemen Negara yang nampaknya menyimpang dari tujuan Negara pada awalnya yang tercantum dalam pancasila. Dalam menyikapi perubahan UUD 1945 tersebut, ada tiga pendapat yang berbeda yang menggarisbawahi proses tersebut. Yang pertama, sebagian masyarakat menginginkan keaslian dari UUD 1945. Yang kedua, sebagian masayarakat menginginkan perubahan terkhir dari UUD 1945. Yang terakhir, ada pendapat publik yang mendukung keberlanjutan dari proses perubahan UUD 1945 hingga mencapai mandat tertinggi dari Negara dan rakyat. Tulisan ini secara fokus akan mendiskusikan isu dari pendapat yang terakhir dari amandemen UUD 1945
\end{abstract}

Kata Kunci: Perubahan UUD 1945, desakralisasi, tujuan bernegara Indonesia.

UUD 1945 dalam perjalanannya menuju tahap perubahan, mengalami sejarah yang cukup panjang. Dimulai pada tanggal 22 Juni 1945, ketika disahkan Piagam Jakarta yang menjadi naskah Pembukaan UUD 1945, yang kemudian dihilangkannya tujuh suku kata terakhir dalam sila pertama Pancasila yakni, " ... dengan kewajiban menjalankan syariat Islam bagi pemeluk-pemeluknya". Naskah rancangan UUD 1945 Indonesia disusun pada masa Sidang Kedua Badan Penyelidik Usaha Persiapan Kemerdekaan (BPUPK) yang dikenal dengan nama dokuritsu zyun- bi tyosakai. ${ }^{1}$ Nama Badan ini tanpa kata "Indonesia" karena hanya diperuntukkan untuk tanah Jawa saja. Di Sumatera ada BPUPK untuk Sumatera. Masa Sidang Kedua tanggal 10-17 Juli 1945. Tanggal 18 Agustus 1945, PPKI mengesahkan UUD 1945 sebagai Undang-Undang Dasar Republik Indonesia.

Dalam kurun waktu 1945-1949, UUD 1945 tidak dapat dilaksanakan sepenuhnya karena Indonesia sedang disibukkan dengan perjuangan mempertahankan kemerdekaan. ${ }^{1}$ Taufiqurrahman Syahuri, Hukum Konstitusi, Proses dan Prosedur Perubahan UUD di Indonesia 1945-2002 (Bogor: Ghalia Indonesia, 2004), h. 107. 
Maklumat Wakil Presiden Nomor X pada tanggal 16 Oktober 1945 memutuskan bahwa KNIP diserahi kekuasaan legislatif, karena MPR dan DPR belum terbentuk. Tanggal 14 November 1945 dibentuk Kabinet Parlementer yang pertama, sehingga peristiwa ini merupakan penyimpangan UUD $1945 .{ }^{2}$

Situasi politik pada Sidang Konstituante 1959 yang kurang kondusif, karena terjadi banyak saling tarik ulur dari berbagai kepentingan partai politik sehingga gagal menghasilkan UUD yang baru. Kemudian pada tanggal 5 Juli 1959, Presiden Soekarno mengeluarkan Dekrit Presiden yang salah satu isinya memberlakukan kembali UUD 1945 sebagai Undang-Undang Dasar, menggantikan Undang-Undang Dasar Sementara 1950 waktu itu. ${ }^{3}$ Namun berbagai penyimpangan UUD 1945 telah dilakukan, di antaranya: Presiden mengangkat Ketua dan Wakil Ketua MPR/DPR dan MA serta Wakil Ketua DPA menjadi Menteri Negara dan MPRS menetapkan Soekarno sebagai presiden seumur hidup.

Dekrit Presiden 5 Juli 1959 yang menetapkan kembalinya UUD 1945 sebagai hukum dasar menjadi pedoman bagi kegiatan penyelenggaraan pemerintahan hingga pada masa Orde Baru (1966-1998). Pemerintah menyatakan kembali menjalankan UUD 1945 dan Pancasila secara murni dan konsekuen. Namun dalam pelaksanaannya terjadi beberapa penyelewengan UUD 1945 yang mengakibatkan terlalu besarnya kekuasaan pada Presiden. Begitu juga terjadi sakralisasi terhadap UUD 1945 yang cenderung irrasional pada masa ini. UUD 1945 tidak diizinkan untuk bersentuhan dengan ide perubahan sama sekali. ${ }^{4}$

Pada masa Orde Baru, UUD 1945 juga menjadi konstitusi yang sangat "sakral", diantaranya melalui sejumlah peraturan berikut: 1) Ketetapan MPR Nomor I/MPR/1983

2 Hendarmin Ranadireksa, Amandemen UUD 1945, Menuju Konstitusi yang Berkedaulatan Rakyat (Jakarta: Pancur Siwah, 2002), h. 65-66.

3 Jimly Asshiddiqie, Konstitusi dan Konstitusionalisme Indonesia (Jakarta: Mahkamah Konstitusi dan PSHTN Fakultas Hukum UI), h. 38-39.

4 Taufiqurrahman Syahuri, Hukum Konstitusi..., h.6. Jimly Asshiddiqie, Konstitusi..., h. 39-40. yang menyatakan bahwa MPR berketetapan untuk mempertahankan UUD 1945, tidak berkehendak akan melakukan perubahan terhadapnya Ketetapan MPR Nomor IV/ MPR/1983 tentang Referendum yang antara lain menyatakan bahwa bila MPR berkehendak mengubah UUD 1945, terlebih dahulu harus minta pendapat rakyat melalui referendum. 2) Undang-Undang Nomor 5 Tahun 1985 tentang Referendum, yang merupakan pelaksanaan TAP MPR Nomor IV/ MPR/1983.

Selain itu pula, dalam perjalanannya, pemerintah Orde Baru sangat diwarnai oleh budaya patrimornial. UUD 1945 dinyatakan bahwa "seluruh menteri merupakan pembantu presiden". ${ }^{5}$ Fungsi pembantu bergeser seperti peran antara pembantu rumah tangga dan majikan. ${ }^{6}$ Ketika Orde Baru tumbang, dengan momentum reformasi, UUD 1945 tidak lagi menjadi satu-satunya produk hukum yang abadi. Dalam kurun waktu 19992002, UUD 1945 mengalami 4 tahap perubahan yang ditetapkan dalam Sidang Umum dan Sidang Tahunan MPR: 1) Sidang Umum MPR 1999, tanggal 14-21 Oktober 1999; Perubahan Pertama UUD 1945, 2) Sidang Tahunan MPR 2000, tanggal 7-18 Agustus 2000; Perubahan Kedua UUD 1945, 3) Sidang Tahunan MPR 2001, tanggal 1-9 November 2001; Perubahan Ketiga UUD 1945, 4) Sidang Tahunan MPR 2002, tanggal 1-11 Agustus 2002; Perubahan Keempat UUD 1945

Dalam menyikapi perubahan tersebut, muncul beberapa arus pemikiran mengenai konstitusi $^{7}$ Negara Indonesia sejalan den5 Penjelasan tentang UUD 1945 Republik Indonesia, Sistem Pemerintahan Negara, butir VI.

${ }^{6}$ Hendarmin Ranadireksa, Amandemen UUD 1945..., h. 67.

${ }^{7}$ Konstitusi secara sederhana dinyatakan sebagai "...a constitution is a document which contains the rules for the operation of an organization". Lihat: Brian Thompson, Textbook on Constitutional and Administrative Law (Edisi ketiga, Blackstone Press ltd., London, 1997), h. 3. Sebagaimana halnya dengan organisasi, Negara juga memiliki konstitusi atau Undang-undang Dasar (terkecuali Israel dan Inggris yang dikenal tidak memiliki konstitusi secara tertulis). Sedangkan menurut Ivo Duchacek, konstritusi adalah "Identify the sources, purposes, and restrains of public power" untuk itu, pembatasan kekuasaan pada umumnya dianggap merupakan corak umum materi konstitusi. Jimly Asshiddiqie, Konstitusi dan Konstitusionalisme..., h. 17-18. 
gan euporia kebebasan yang selama hampir empat dekade mengalami pembelengguan struktur. Pada saat itu, ada tiga arus yang berkembang dalam menyikapi perubahan atau amandemen konstitusi. Pertama, mereka yang tidak menginginkan perubahan, kedua mereka yang menginginkan perubahan secara perlahan dan mencukupkan perubahan sampai amandemen ke-empat, dan ketiga mereka yang menginginkan dekonstruksi konstitusi secara radikal dan perubahan masih harus terus dilakukan. Tulisan ini akan berdasar pada arus ketiga yang menginginkan perubahan secara total.

Ada beberapa alasan kenapa penulis mengambil sikap dan memilih untuk dilakukannya amandemen UUD 45 secara menyeluruh, di antaranya:

\section{Desakralisasi Konstitusi}

Hampir selama empat dekade, nuansa pemikiran diarahkan untuk seragam menerima doktrin dari negara. Selama itu pula, tidak pernah ada dorongan untuk menggugat UUD 1945. UUD 1945 menjadi mitos yang diagung-agungkan dan dilanggengkan dengan berbagai pengajaran untuk menjadi warga negara yang baik dan benar di berbagai institusi. Karena itu pulalah, Penataran mengenai Pedoman Penghayatan dan Pengamalan terhadap Pancasila (P4) menjadi "password" ketika masuk ke berbagai tingkatan bagi berbagai tingkatan pendidikan. Yang menarik dalam metode yang dikembangakan dalam pengajaran tersebut adalah bagaimana supaya peserta hafal dan mematuhi terhadap isi dari Undang-Undang Dasar tersebut, bahkan hal tersebut diuji dengan kontes adu hafalan yang dikemas dalam lomba P4.

Ketiadaan dialektika yang secara terbuka mengupas, bahkan mengkritisi terhadap isi dari konstitusi yang semestinya menjadi identititas komunal dalam tingkatan negara yang kemudian membentuk karakter dan identitas personal setiap warga negara. Dengan tidak adanya ruang dialog tersebut, yang terjadi adalah pelapukan ideologi. Doktrin bahwa UUD 1945 adalah sempur- na, UUD 45 adalah bukti sejarah, dan UUD 1945 adalah konstitusi yang bersifat luwes, dan lain-lain, mempersulit terjadinya amandemen terlebih lagi jika dilakukan secara total. Keyakinan bahwa menafikan UUD 1945 sama dengan menafikan eksistensi perjuangan bangsa Indonesia yang ditebus dengan darah dan air mata, justru menafikan adanya kebutuhan untuk merubah sistem ketatanegaraan menuju bangsa Indonesia yang lebih adil dan beradab sesuai dengan dasar negara kita yaitu Pancasila.

Jika melihat sejarahnya, UUD 1945 merupakan hasil para aktor kemerdekaan pada saat itu mengingat keadaan yang mendesak kebutuhan akan konstitusi. UUD 1945 yang disahkan berlaku pada tanggal 18 Agustus 1945 adalah konstitusi yang diistilahkan oleh Soekarno pada pembukaan sidang PPKI sebagai "UUD Darurat yang dibuat secara kilat", 8 atau revolutie grownwet, merupakan UU yang bersifat sementara dan harus diganti dengan yang baru jika negara sudah merdeka dan berdiri serta kondisi lebih memungkinkan. ${ }^{9}$ UUD 1945 inipun pernah tidak diberlakukan dan diberlakukan lagi ketika keadaan darurat yaitu dengan Dekrit Presiden 1959. Sampai diberlakukannya pada tahun 1959, UUD 1945 sebenarnya memang belum sempat diterapkan dengan sebaik-baiknya hingga akhirnya muncul orde baru dengan jargon "menegakkan UUD 1945 secara murni dan konsekuen". Untuk itu tidak ada landasan kuat untuk tetap mempertahankan UUD 1945, terlebih lagi dalam aturan tambahan Pasal I dan Pasal II UUD 1945 sendiri, ${ }^{10}$ menyatakan sifat interim UUD 1945 tersebut. $^{11}$

Perubahan adalah keniscayaan. Dengan demikian dimaksudkan dapat mengikuti irama perubahan dengan tanpa meninggalkan nilai-nilai luhur yang dijunjung ting-

\footnotetext{
${ }^{8}$ Moh. Mahfud MD., Hukum Tak Kunjung Tegak (Bandung: PT. Citra Aditya Bakti, 2007)..., h. 221.

${ }_{9}^{9}$ Jimly Asshiddiqie, Konstitusi dan Konstitusionalisme..., h. 34 .

${ }^{10}$ Aturan Tambahan Pasal II UUD 1945 menyatakan "Dalam enam bulan sesudah Majelis Permsyawaratan Rakyat dibentuk, Majelis ini bersidang untuk menetapkan Undang-undang Dasar"

${ }^{11}$ M. Mahfud MD., Hukum Tak Kunjung Tegak..., h. 221.
} 
gi oleh bangsa Indonesia, adalah salah satu upaya dalam membangun bangsa Indonesia lebih maju tanpa melepaskan nilai-nilai kemanusiaan. Nilai-nilai luhur inilah yang kemudian dicarikan bentuknya yang bisa berubah dari waktu ke waktu. Ketika nilainilai luhur direduksi menjadi salah satu bentuk yang berupa UUD 1945, maka yang terjadi adalah pelanggaran Hak Asasi Manusia atas nama konstitusi. Sejarah membuktikan bahwa berbagai pembantaian terhadap para aktivis dibenarkan atas nama mempertahankan ideologi negara.

Para perancang UUD 1945 tidak berniat untuk menciptakan konstitusi yang akhirnya menjadi agama baru dalam bernegara. Mereka tahu bahwa tidak ada UUD di dunia ini yang tidak bisa ditubah. K. C. Wheare, seorang pakar konstitusi mengatakan bahwa UUD suatu negara merupakan hasil kesepakatan dari situasi politik, sosial, dan ekonomi pada waktu tertentu. Jika situasi, dan kebutuhan masyarakat berubah, maka UUD sebagai resultante juga dapat berubah. Sehingga menurutnya, setiap UUD harus memiliki pasal yang mengatur masalah perubahan. ${ }^{12}$ Konstitusi di setiap negara tentunya berbeda satu dengan yang lainnya, sesuai dengan pilihan politiknya. Bisa saja menganut teori yang sama, tetapi dalam menghadapai kondisi dan pengalaman yang berbeda, maka secara tertulis, konstitusi tersebut menjadi berbeda dengan beragam variasi dan alternatif.

Dalam hal apapun, keajegan yang awalnya dibentuk oleh sistem, dipatuhi dan dilaksanakan sehingga menjadi budaya, jika tertutup dan menutup diri dari perubahan, yang terjadi adalah sakralisasi. Hal inilah yang berbahaya karena sakralisasi kemudian tidak lagi menggunakan pikiran yang jernih dan rasional, bahkan tidak pula menggunakan rasa. Yang ada adalah keyakinan yang frigid dari hal apapun. Sehingga langkah awal dalam menciptakan perubahan yang lebih baik adalah, sikap terbuka akan perubahan dan desakralisasi berbagai ideologi termasuk konstitusi.

${ }^{12}$ KC. Wheare, The Modern Costitutions (London-New York-Toronto: Oxford University Press, $3^{\text {rd }}$ Impression, 1975), h.67-68.

\section{Meminimalisir dan meniadakan intervensi} Asing terhadap kedaulatan bangsa Indonesia

Tidak dapat dipungkiri lagi bahwa perubahan pola dunia yang kita kenal dengan istilah globalisasi ternyata telah merusak sendi-sendi kehidupan masyarakat terutama kelompok marginal. Globalisasi, sebagai tendensi sistem pemikiran kapitalisme, beroperasi berdasarkan prinsip: kebebasan bergerak modal, penghancuran kekuasaan negara bangsa sebagai sebuah entitas politik, dan pelemahan secara struktural posisi rakyat pekerja. Dasar pemikirannya, "semakin kapital beroperasi secara global, semakin negara nasional terintegrasi ke dalam satu pasar bersama, maka kemakmuran bersama bisa diwujudkan. Konspirasi antara globalisasi yang berada dalam genggaman kekuasaan pemodal dan legislatif dalam ranah negara, seringkali tidak memperhatikan kepentingan masyarakat sipil secara umum. Prinsipnya adalah: kebijakan dibuat untuk memenuhi kepentingan pemodal adalah suatu persoalan. Dampaknya terhadap usaha kecil masyarakat dan lingkungan adalah persoalan lain.

Hal tersebut menjadi keniscayaan ketika fungsi DPR-MPR sebagai wakil rakyat untuk mengatur kebijakan yang seharusnya berpihak kepada masyarakat, menjadi berpihak kepada pemodal asing. Intervensi dari pihak asing baik itu pemodal, organisasi internasional, pemberi utang (IMF dan Word Bank) nampak sekali dalam pembuatan beberapa undang-undang. Contoh konkrit adalah UU tentang Penanaman Modal yang baru-baru ini disahkan.

Dalam teori kedaulatan,,$^{13}$ ada tiga term penting yang harus dimiliki oleh suatu nega-

\footnotetext{
${ }^{13}$ Kedaulatan (sovereignty) merupakan konsep yang biasa dijadikan objek dalam filsafat politik dan $\mathrm{Hu}-$ kum Ketatanegaraan. Secara sederhana, kedaulatan berkaitan dengan gagasan mengenai kekuasaan tertinggi baik dalam bidang ekonomi maupun politik. Lihat: Jimly Asshiddiqie, Gagasan Kedaulatan Rakyat dalam Konstitusi dan Pelaksanaannya di Indonesia, Jakarta, Ichtiar Baru Van Hoeve, 1994. Kedaulatan juga sering diartikan sebagai kebebasan dan kemerdekaan dari kekuasaan lain selain dirinya. Konsep ini pertama kali diluncurkan sebagai wacana pengetahuan oleh Jean Bordin (1530-1596) dengan bukunya "Sir Livres de la Republique". Lihat: Jimly Asshiddiqie, Konstitusi dan Konstiusionalisme Indonesia, h. 96-97.
} 
ra dalam kapasitasnya sebagai international personaliy, sekaligus sebagai subjek hukum dalam hukum internasional. Pertama adalah Intern kedaulatan yaitu suatu negara dikatakan berdaulat jika negara tersebut memiliki kebebasan dalam mengatur dan memelihara negaranya seperti membuat kebijakan/ hukum untuk kepentingan warga negaranya. Kedua, ekstern kedaulatan yaitu negara bebas dan mandiri menentukan dengan siapa bekerja sama dan membangun relasi, termasuk ikut serta sebagai anggota dalam organisasi intenasional. Ketiga, negara memiliki hak penuh untuk mengelola dan memanfaatkan sumber daya alam yang berada dalam batas teritorialnya. ${ }^{14}$

Dengan berkaca pada teori kedaulatan di atas, nampaknya Indonesia belum benarbenar memiliki ketiga aspek tersebut. Kedaulatan yang dimiliki mengalami erosi seiring dengan banyaknya intervensi pemodal dan lembaga keuangan internasional (LKI) dalam menentukan nasib bangsa Indonesia. Dengan patuhnya Indonesia terhadap aturan-aturan dalam WTO menuju perdagangan bebas, melemahkan posisi pemerintah sebagai pengatur negara menuju masyarakat yang adil dan makmur sebagaimana cita-cita bangsa Indonesia. Selain itu pula, atas perintah IMF dan Word Bank, Pemerintah Indonesia memilih untuk taat dalam melakukan deregulasi ekonomi, privatisasi pendidikan, mencabut subsidi atas layanan umum yang menyangkut hajat hidup orang banyak. Pilihan sikap seperti ini diikuti dengan aturanaturan baik dalam skala nasional maupun daerah yang lebih berpihak kepada pemodal asing.

Jika para pemangku kebijakan menyadari, intervensi yang dihalalkan tersebut di atas, telah merusak cita-cita luhur bangsa yang semestinya menjadi ruh dalam keseluruhan sistem materi Undang-undang Dasar, termasuk Undang-undang beserta turunan-

\footnotetext{
${ }^{14}$ Ekstern kedaulatan merupakan ciri kedaulatan yang dimiliki dalam wacana hukum internasional. Yaitu kekuasaan mutlak suatu Negara untuk berhadapan dengan kekuasaan lain. Lihat: C.F. Strong, Modern Political Constitution (London: The English Language Society, 1966), h. 80.
}

nya. Alinea Pertama Pembukaan UUD 1945 menegaskan bahwa bangsa Indonesia yakin bahwasannya kemerdekaan itu adalah hak asasi segala bangsa, dan karena itu pula, segala bentuk penjajahan di atas dunia harus dihapuskan, karena tidak sesuai dengan peri kemanusiaan dan peri keadilan. ${ }^{15}$ Penjajahan modern tidak lagi menggunakan senapan atau meriam seperti zaman kolonial Belanda dulu, tetapi lebih terstruktur melalui kekuasaan dalam bingkai ilmu pengetahuan dan dekapan organisasi-organisasi internasional. Neo-imperialisme terjadi dengan cerdas dan ramah sehingga tidak menimbulkan resistensi dan perlawanan yang berarti.

Gambaran di atas merupakan potret buram tata Pemerintahan di Indonesia sehingga pilihan bijaknya adalah bagaimana membuat sistem yang mengatur partisipasi aktif rakyat dalam mengambil kebijakan. Hal yang paling sederhana adalah, masyarakat diberikan kesempatan untuk memberikan masukan dan mengawasi, serta membatalkan sebuah undang-undang melalui badan negara tertentu. Peran yang diberikan tidak hanya sekedar ceremonial seperti hearing, namun juga setelah mendengar, para wakil rakyat tersebut menjadikan masukan yang diberikan masyarakat sebagai sebuah bahan penting dalam pembuatan kebijakan. Sikap terbuka dari para wakil rakyat, merupakan salah satu cara dalam meminimalisir peran aktif pemodal asing dalam pembuatan kebijakan. Namun menunggu keterbukaan tersebut muncul, tidaklah cukup jika tidak didorong oleh adanya ketentuan yang jelas dalam konstitusi. Untuk itu, amandemen UUD 1945 belum tuntas dan harus selalu terbuka untuk berubah.

Amandemen UUD 1945 saat ini telah memunculkan sistem ketatanegaraan yang baru dengan menguatnya format dan mekanisme check and balance oleh lembaga Yudisial dan pengaturan secara rinci tentang perlindungan HAM bagi warga negara. ${ }^{16} \mathrm{Hal}$ ini di-

\footnotetext{
${ }^{15}$ Jimly Asshiddiqie, Konstitusi dan Konstitusionalisme..., h. 51.

${ }^{16}$ Moh. Mahfud MD., Perdebatan Hukum Tata Negara Pasca Amandemen Konstitusi (Jakarta: LP3ES, 2007)..., h. 47.
} 
harapkan akan mewujudkan kehidupan bernegara yang independen dan beradab.

Amandemen UUD 1945 yang sudah dilakukan, menjadi celah baru dalam mewujudkan kedaulatan negara. Misalnya mengenai kekuasaan kehakiman yang dulu berpuncak pada Mahkamah agung, sekarang berada pada dua lembaga yaitu Mahkamah Agung dan Mahkamah Konstitusi. Kehadiran Mahkamah Konstitusi, yang secara yuridis berperan dalam menguji perkara ketatanegaraan, termasuk menilai UU berdasarkan konstitusi, semestinya memiliki kewenangan dalam menilai isi dari undang-undang supaya berpihak kepada rakyat dan menilai alur pembuatan UU sehingga dipastikan bebas dari intervensi asing.

Amandemen UUD 1945 juga membentuk Komisi Yudisial yang berwenang untuk mengangkat dan mengawasi hakim agung. Terlepas dari perdebatan dan ketumpangtindihan yang ada, dengan sistem tata negara yang baru, memberikan angin segar demi terwujudnya undang-undang yang pro terhadap masyarakat terutama kelompok marginal. Untuk itu, konstitusi harus dirubah sesuai dengan semangat di atas, sehingga tercipta hukum yang adil dan mandiri.

Agenda selanjutnya yang perlu dilakukan dalam amandemen adalah menentukan sistem ekonomi yang sesuai dengan nilai-nilai keadilan dan berpihak kepada kesejahteraan masyarakat pada umumnya, dengan mengutamakan memiimalisir kesenjangan strata ekonomi yang tinggi. Pengentasan kemiskinan seharusnya menjadi agenda utama dalam pembuatan kebijakan di berbagai sektor sesuai dengan tujuan-tujuan Pembangunan Milenium (Millenium Development Goals). ${ }^{17}$

\footnotetext{
${ }^{17}$ Millenium Development Goals (MDGs) adalah Tujuan Pembangunan Milenium yang tertuang dalam "Deklarasi Milenium" dan disepakati oleh 189 negara anggota PBB, termasuk Indonesia, dalam KTT Milenium PBB pada bulan September 2000. Tujuan Pembangunan Milenium disebut sebagai suatu pendekatan yang inklusif dalam pemenuhan hak-hak dasar manusia, terdiri dari delapan tujuan (goals) yang dijabarkan kedalam delapan belas target dan lima puluh dua indikator terkait untuk dapat dicapai dalam jangka waktu 25 tahun antara 1990 dan 2015. Deklarasi Milenium menandai abad perjuangan yang lebih menitik beratkan pada hak ekonomi sosial dan budaya, dan mendorong
}

Menghadapi persaingan pasar bebas, market socialism dapat menjadi alternatif dalam memilih kerangka ekonomi yang efektif dalam menciptakan kesejahteraan sosial. Hal ini, harus secara jelas tercantum dalam Undangundang Dasar.

\section{Mengembalikan Sistem Hukum yang Bermoral}

Sejak lebih-kurang 200 tahun negara-negara di dunia menggunakan konsep hukum modern, maka pelan-pelan hukum telah memisahkan diri dari moral. Praksis hukum menghadapi pertanyaan yang sifatnya spesialistis, teknologis, bukan pertanyaan moral. Keadaan yang demikian itu sangat kuat tampak pada hukum sebagai profesi. Kaum profesional adalah orang-orang yang ahli dalam perkara perundang-undangan, tetapi kita tidak bisa bertanya kepada mereka persoalan moral atau moralitas. Ekses praktik hukum di Amerika yang sudah menjadi bisnis mengundang orang untuk berkomentar, bahwa sifat kesatriaan, menolong orang yang susah, sudah semakin luntur. Hal ini menular pada budaya hukum di beberapa negara berkembang termasuk Indonesia.

Kebaikan publik (public good) yang selama ini menjadi kekayaan bangsa Indonesia, seperti gotong royong, tepo saliro, menjadi luntur dengan semakin dekatnya pemerintah Indonesia dengan kebijakan-kebijakan global yang menuntut adanya tanggung jawab personal. Ekonomi yang pada awalnya menjadi sasaran kapitalisme global, menciptakan ruang-ruang baru yang menggeser kearifan lokal yang ada di ranah pertiwi ini.

Saat ini, hukum modern yang menjadi teknologis dan profesionalistis, semakin mengalami deregulasi moral. Sejak itu hukum sudah kehilangan bobotnya sebagai institusi moral dan keadilan. Kualitas seperti itulah yang saat ini kita hadapi, yaitu saat kebebasan global akan memberikan kesempatan para lawyer asing berhamburan ke Indonesia. Sesuai dengan model keempat dalam

menguatnya gerakan global yang ditujukan untuk penghapusan kemiskinan. Lihat: Laporan Pecapaian MDGs Versi Masyarakat Sipil, Oktober 2005. 
aturan GATS, ${ }^{18}$ negara kita tidak memiliki kewenangan untuk melarang arus tenaga kerja profesional masuk ke Indonesia. Kalau memang hukum modern mengalami deregulasi moral, salah satu tugas yang kita hadapi adalah bagaimana mengembalikan sisi moral dari hukum itu ke tempatnya.

Dekrit Presiden 9 Juli 1959 dalam Konsiderannya menyatakan bahwa "Piagam Jakarta menjiwai UUD 1945 dan merupakan satu kesatuan dengan UUD $1945 .{ }^{19}$ Pernyataan ini menujukkan bahwa antara Undangundang Dasar 1945 dan juga UUD apapun yang berlaku di Indonesia, merupakan pencerminan piagam Jakarta yang secara eksplisit tertuang dalam butir-buir pembukaan UUD 1945.

Dua pokok pikiran yang terdapat dalam pembukaan UUD 1945 adalah mewujudkan keadilan sosial bagi seluruh rakyat Indonesia, dan juga merupakan negara yang berke-Tuhanan Yang Maha Esa menurut Dasar Kemanusiaan Yang Adil Dan Beradab. ${ }^{20}$ Keadilan dalam hukum merupakan tujuan yang harus dicapai dalam pembuatan dan penegakkan hukum. Keyakinan akan Tuhan Yang Maha Esa yang termanifestasikan dalam ketaatan menjalankan hukum yang bermoral sesuai dengan perintah Tuhan, adalah amanah para funding people yang harus dipenuhi dalam kehidupan bernegara di Indonesia. Kita dapat membayangkan berbagai akibat apabila dimensi moral tersebut terabaikan.

Untukitulah, amandemen selanjutnya masih diperlukan dengan memuat klausul baru yang mampu mengembalikan citra hukum di Indonesia lebih humanis dan menjunjung tinggi nilai moralitas dan perlindungan Hak Asasi Manusia (HAM) yang sejak awal menjadi tujuan dilakukannya amandemen UUD 1945 sampai yang keempat. ${ }^{21}$ Dengan peru-

\footnotetext{
${ }_{18}$ GATs (General Agreement on Tariffs and Services) adalah perjanjian yang membahas masalah jasa sebagai sala satu paket perjanjian dalam WTO (World Trade Organization).

19 Endang Saifuddin Anshari, Piagam Jakarta 22 Juni 1945 (Bandung: Pustaka Salman ITB, 1981), h. 117.

${ }^{20}$ Pembukaan UUD 1945, Jimly Asshiddiqie, Konstitusi dan Konstitusionalisme..., h. 51.

${ }^{21}$ Abdul Mukhtie Fadjar, Hukum Konstitusi dan Mahkamah Konstitusi..., h. 49.
}

bahan struktur hukum, maka diharapkan menjadi langkah awal dalam merubah budaya dan substansi hukum di Indonesia.

\section{Mengembalikan Kedaulatan kepada Rakyat}

Salah satu tuntutan Reformasi 1998 adalah dilakukannya perubahan (amandemen) terhadap UUD 1945. Latar belakang tuntutan perubahan UUD 1945 antara lain karena pada masa Orde Baru, kekuasaan tertinggi di tangan MPR (dan pada kenyataannya bukan di tangan rakyat), kekuasaan yang sangat besar pada Presiden, adanya pasalpasal yang terlalu "luwes" (sehingga dapat menimbulkan mulitafsir), serta kenyataan rumusan UUD 1945 tentang semangat penyelenggara negara yang belum cukup didukung ketentuan konstitusi.

Tujuan perubahan UUD 1945 waktu itu adalah menyempurnakan aturan dasar seperti tatanan negara, kedaulatan rakyat, HAM, pembagian kekuasaan, eksistensi negara demokrasi dan negara hukum, serta hal-hal lain yang sesuai dengan perkembangan aspirasi dan kebutuhan bangsa. Perubahan UUD 1945 dengan kesepakatan di antaranya tidak mengubah Pembukaan UUD 1945, tetap mempertahankan susunan kenegaraan (staat structuur) kesatuan atau selanjutnya lebih dikenal sebagai Negara Kesatuan Republik Indonesia (NKRI), serta mempertegas sistem pemerintahan presidensiil.

Dalam pasal 1 ayat 2 UUD 1945 pra amandemen mengenai kedaulatan mengatakan bahwa "Kedaulatan adalah di tangan rakyat, dan dilakukan sepenuhnya oleh Majelis Permusyawaratan Rakyat". Selanjutnya Penjelasan tentang UUD 1945 Bab II tentang Majelis Permusyawaratan Rakyat, pasal 2 berbunyi:

"Maksudnya ialah supaya seluruh rakyat, seluruh golongan, seluruh daerah akan mempunyai wakil dalam Majelis sehingga Majelis itu akan betul-betul dapat dianggap sebagai penjelmaan rakyat"

UUD 1945 pra amandemen menempatkan MPR sebagai lembaga tertinggi negara yang memiliki kekuasaan tertinggi. MPR 
adalah lembaga tertinggi negara rakyat dan melakukan sepenuhnya kedaulatan rakyat, dan secara eksplisit dikatakan bahwa MPR adalah penjelmaan seluruh rakyat Indonesia. Dalam hal ini, ada kerancuan konsep antara kedaulatan dan faham integralistik, antara faham negara hukum dengan faham negara kekuasaan. ${ }^{22}$

Dengan melihat pasal tersebut di atas, nampak adanya ketidakjelasan mengenai hakekat kedaulatan rakyat. Jika kedaulatan berarti menyerahkan kemerdekaan kepada pihak lain, berarti menyalahi hakekat kedaulatan. Jika MPR dianggap sebagai penjelmaan rakyat, secara tidak langsung meniadakan keberadaan rakyat. Peran dan keberadaan rakyat menurut UUD 1945 pra amandemen menjadi tidak jelas karena MPR diberi kekuasaan dan kewenangan secara mutlak sedangkan pertanggungjawabannya tidak jelas mengingat keanggotaannya berasal Utusan Daerah, dan KPU yang memilih anggota MPR utusan golongan.

Jimly Asshiddiqie berpendapat bahwa bangsa Indonesia menempatkan kedaulatan rakyat (democratie) dan kedaulatan hukum (nomocratie) dalam posisi yang sama dan harus beriringan. ${ }^{23}$ Masing-masing tidak dapat terpisahkan dan dicermin dalam bentuk negara yang demokratis (democratiche rechsstaat) sekaligus sebagai negara demokrasi yang berdasarkan atas hukum (constitutional democracy). Untuk itulah, demokrasi tidak hanya menjadi slogan saja, namun harus secara jelas tertuang secara jelas dalam konstitusi negara.

Pertanyaan mengenai ada atau tidak adanya kedaulatan rakyat secara hakiki menjadi penting mengingat kedaulatan tersebut telah dilakukan sepenuhnya oleh MPR. Tidak ada satu pasal dalam UUD 1945 pra amandemen yang menyebut tentang pemilihan umum dan referendum, sehingga pemerintah dapat tetap melaksanakan fungsinya dengan atau tanpa pemilihan umum mengingat UUD ${ }^{22}$ Adnan Buyung Nasution yang dikutip oleh Abdul Mukhtie Fadjar, Hukum Konstiusi dan Mahkamah Konstitusi (Jakarta: Konstitusi Press, 2006)..., h. 10.

${ }^{23}$ Jimly Asshiddiqie, Konstitusi dan Konstitusionalisme..., h. 57.
1945 pra amandemen sangat terbuka untuk ditafsirkan.

Persoalan lain yang terjadi adalah mengenai kekuasaan eksekutif. Presiden memiliki pengaruh yang sangat dominan yaitu sebagai pemegang kekuasaan pemerintah (chief executive) dan sebagai kepala negara dengan hak-hak konstitusionalnya (lazim disebut hak prerogatif), serta memiliki kekuasaan untuk membentuk undang-undang. Hal ini menyebabkan lahirnya kekuasaan otoriter yang salah satunya disebabkan oleh banyaknya pasal-pasal yang luwes dalam UUD 1945 pra amandemen sehingga menimbulkan multi tafsir. Dengan sistem politik yang executive heavy seperti ini, tidak mampu memunculkan mekanisme check and balance yang seimbang dan proporsional. ${ }^{24}$

Sejarah membuktikan bahwa dengan memberlakukan UUD 1945 dalam dua rezim yang berbeda yaitu pada Masa Demokrasi Terpimpin (1949-1966), dan Masa Demokrasi Pancasila (1966-1998), sistem politik yang muncul adalah otoriterisme. ${ }^{25}$ Pada periode rezim Demokrasi Parlementer (19451959), nampak bahwa sistem politik yang tampil adalah demokratis. Hal ini terjadi karena pada masa tersebut, UUD 1945 tidak diberlakukan meskipun tanpa mencabutnya secara resmi. ${ }^{26}$ Salah satu contoh tidak diberlakukannya UUD 1945 adalah dengan menetapkan sistem parlementer di bawah pimpinan Syahrir, padahal menurut UUD 1945, sistem yang harus diberlakukan dalam pemerintahan adalah sistem presidensiil. ${ }^{27}$

Dengan UUD 1945 amandemen, MPR bukan lagi lembaga tertinggi negara dan rakyat meletakkan kedaulatannya pada MPR, melainkan hanya berwenang dalam menetapkan dan mengubah UUD, melantik presiden dan wakil presiden, serta memberhentikan presiden dan wakil presiden. MPR sekarang ini sejajar dengan lembaga-lembaga lain se-

\footnotetext{
${ }^{24}$ Moh. Mahfud MD, Perdebatan Hukum Tata Negara..., h.38.

${ }^{25}$ Moh. Mahfud MD, Hukum Tak Kunjung Tegak..., h. 220-221.

${ }^{26}$ Moh. Mahfud MD, Hukum..., h. 220-221.

${ }^{27}$ Jimly Asshiddiqie, Konstitusi..., h. 34-36.
} 
perti MA, Presiden, DPR MK dan BPK. ${ }^{28}$

Perubahan lain yang terjadi dengan UUD 1945 adalah presiden sebagai pemegang kekuasaan eksekutif tidak lagi memegang kekuasaan membentuk UU yang telah bergeser ke tangan DPR, melainkan hanya berhak mengajukan RUU ke DPR, memberikan persetujuan bersama DPR dan mengesahkan RUU menjadi UU. Selain itu pula, pemilihan presiden dan wakil presiden diselenggarakan secara langsung sesuai konstitusi. Mekanisme impeachment terhadap presiden dan wakil presiden menjadi salah satu alat dalam mengawasi kinerja presiden sehingga meminimalisir terjadinya otoriterisme. UUD 1945 amandemen juga mengatur bahwa dalam pembentukan dan pengubahan, serta pembubaran kementrian harus diatur dengan UU, tidak bebas seperti sebelumnya. Dengan adanya amandemen ini, baik

${ }^{28}$ Moh. Mahfud MD, Perdebatan Hukum Tata Negara..., h.31.

\section{DAFTAR PUSTAKA}

Anshari, Endang Saifuddin. 1981. Piagam Jakarta 22 Juni 1945. Bandung: Pustaka Salaman ITB.

Asshiddiqie, Jimly. 1994. Gagasan Kedaulatan Rakyat dalam Konstitusi dan Pelaksanaannya di Indonesia. Jakarta: Ichtiar Baru Van Hoeve.

Asshiddiqie, Jimly. 2004. Konstitusi dan Konstitusionalisme Indonesia. Jakarta: Mahkamah Konstitusi dan Pusat Studi Hukum Tata Negara Universitas Indonesia.

Fadjar, Abdul Mukthie. 2006. Hukum Konstitusi dan Mahkamah Konstitusi. Yogyakarta: Citra Media.

Mahfud MD, Moh. 2007. Perdebatan Hukum Tata Negara Pasca Amandemen Konstitusi. Jakarta: LP3ES. legislatif maupun eksekutif tidak dapat dengan dengan mudah melakukan tindakan yang bersebrangan dengan nilai-nilai kerakyatan. Meminimalisir peran dan kekuasaan badan-badan tinggi negara, merupakan salah satu upaya dalam mengembalikan kedaulatan kepada rakyat dan pemegang kekuasaan.

\section{Kesimpulan}

Amandemen masih perlu dilakukan yang sesuai dengan ruh kedaulatan rakyat dan keadilan. Apabila ruh kedaulatan rakyat telah menjiwai pasal-demi pasal dalam UUD, maka rakyat akan menghayati keyakinan bahwa bangsa dan negara sesungguhnya berada dan menuju pada arah yang benar. Pancasila sebagai falsafah negara, menjadi spirit yang harus dimiliki dalam setiap pembuatan kebijakan, dan undang-undang dasar menjadi langkah awal dalam mewujudkan hal tersebut. Untuk itu, amandemen UUD 1945 adalah sebuah keniscayaan.

Mahfud MD, Moh. 2007. Hukum Tak Kunjung Tegak. Bandung: Citra Aditya Bakti.

Syahuri, Taufiqurrohman. 2004. Hukum Konstitusi, Proses dan Prosedur Perubahan UUD di Indonesia 1945-2002. Bogor: Ghalia Indonesia.

Ranadireksa, Hendarmin. 2002. Amandemen UUD 1945, Menuju Konstitusi yang Berkedaulatan Rakyat. Jakarta: Pancur Siwah.

Strong, C.F. 1966. Modern Political Constitution. London: The English Language Society.

Thompson, Brian. 1997. Textbook on Constitutional and Administrative Law. Edisi ketiga. London: Blackstone Press ltd.

Wheare, K.C. 1975. The Modern Costitutions. London-New York-Toronto: Oxford University Press, $3^{\text {rd }}$ Impression. 